\title{
Digital transformation of the energy sector: a case of Russia
}

\author{
Galina Chebotareva ${ }^{1 *}$ \\ ${ }^{1}$ Academic Department of Energy and Industrial Enterprises Management Systems, Graduate School \\ of Economics and Management, Ural Federal University, Mira str. 19, 620002 Yekaterinburg, Russian \\ Federation
}

\begin{abstract}
The article outlines the main stages of the digital transformation of the energy sector of Russia since 2014. The methodological framework of the summary is composed of the key federal laws and industrial regulations that formed the foundation of the digitalization of the Russian energy sector. The study revealed two focus segments for Russian energy transformation. The first one deals with the development of the methodological framework for digital transformation (departmental project "Digital Energy"). The second one works towards the development of new technical solutions, their active field testing and elimination of emerging administrative barriers (EnergyNet road map, "Unified Technical Policy Power Supply Reliability" project). It has been established that technological development trends in the Russian energy sector generally match those in the rest of the world (smart energy, distributed generation, renewable energy, consumer services etc.). Private projects that are being implemented as part of these initiatives prove highly efficient technically and economically and are attracting wide attention in the global energy market.
\end{abstract}

\section{Introduction}

The traditional structure of the energy system of Russia is currently out of date. The average rate of depreciation for fixed assets is 70 to $80 \%$ depending on the specialization of the energy business [1, 2], while the asset renewal rate is usually not so high. New groundbreaking technologies that are emerging in traditional generation as well as in alternative energy should be put in use. At the same time, the development of the energy market should take into account constantly growing demand for electric power and meet qualitatively new demands of society (environmental friendliness, availability, mobility, digital quality) [3-6]. This is only possible with the start of new investment cycles that are aimed not only at replacing obsolete energy capacity, but also at the adoption of new digital technologies at energy facilities [7-9].

As a result, the transformation of the national energy sector that is gaining pace, new laws and regulations that are being drafted, national, sectoral and ministerial programs that have been approved for implementation and emerging technical solutions and administrative initiatives call for systematization of a large amount of incoming information. It is, therefore,

\footnotetext{
* Corresponding author: g.s.chebotareva@urfu.ru
} 
the objective of this study to produce an overview of digital transformation methods and practices that are currently in use in the Russian energy sector. This article draws upon upto-date laws and regulations addressing the digitalization of the economy and industries, road maps, project profiles, and other official sources documenting the implementation of digital projects.

The practice-related subject matter and objective of the article determine the following structure of the work. Part 2 describes the key stages of the digital development of the Russian economy, including the energy sector. Part 3 looks at the tangible results of the implementation of the "EnergyNet" program with regard to four types of projects. Part 4 investigates the methodological side of the "Digital Energy" project. Part 5 presents the current practical achievements of the "Unified Technical Policy - Power Supply Reliability" project. In the Conclusions part of the article, the main results are summarized and technological trends that accompany the digital transformation of the Russian energy sector are described.

\section{Main stages of Russian energy sector digitalization}

A strategy towards sweeping digitalization of the Russian economy was formally announced on 4 December 2014 during the Russian president's annual address to the Federal Assembly [10]. In the address, Vladimir Putin sent the goal of "creating a system of long-term forecasts feeding a strategy of choosing suitable technologies in the next 10 to 15 years". The ultimate goal of the initiative is to ensure national security, improve quality of life, and promote industries operating in a new technological environment. The National Technology Initiative (NTI) took shape by mid-2015 [11, 12] and was officially approved in 2016 [13] to run till 2035. The initiative comprises 8 road maps and around 54 projects of the NTI Fund and 578 projects of the Foundation for Assistance to Small Innovative Enterprises [14]. The NTI's road maps include "Neuronet", "Technet", "Healthnet" and a few others. Their implementation should forge new markets and create conditions for Russia's global technological leadership.

It is within the framework of the NTI that the "EnergyNet" action plan for the digitalization of the national energy sector has been implemented since 2016-2017. The mission of this action plan is largely in line with the NTI, but is customized to the needs of the energy sector. The ultimate goal of EnergyNet is to secure the global technological leadership of Russian companies in new energy markets through forward-looking development of digital transformation practices for the national electric power infrastructure. The specific goals of the project $[15,16]$ are associated with:

- Penetration of new energy markets;

- Development/adoption of promising smart energy technologies and services;

- Import of technologies under development from "target countries" (e.g. BRICS member states);

- Energy asset modernization;

- Training of personnel for the successful development of the energy market;

- Refinement of legislation and elimination of administrative barriers in the course of the transition to a new energy paradigm;

- Breaking the constraints of infrastructure by expanding a chain of research centers, laboratories, and experimental sites;

- Overcoming funding constraints, primarily with the help of private investments;

- Fulfilling the challenges of economic development facing the energy sector.

The key segments of the "EnergyNet" road map are "reliable and flexible distribution networks", "smart distributed energy", and "consumer services". 
In 2018, the decree of the Russian President [17] set the key targets for the Russian Federation national program "Digital Economy" [18, 19] through to 2024:

a) a three-fold increase in domestic expenditures on the development of the digital economy;

b) creation of sustainable and safe information and telecom infrastructure for high-speed transmission, processing and storage of large data volumes that would be accessible to all organizations and households (access to the internet, $5 \mathrm{G}$ network rollout, data protection);

c) predominant use of domestic software by government agencies, local governments and organizations;

d) boosting the efficiencies of the key industries;

e) training of highly qualified personnel for the digital economy.

This decree [17] also sets a number of tasks directly applicable to the development of digital energy:

- transformation of priority industries, including energy infrastructure, through introduction of digital technology and platform solutions;

- guaranteed provision of affordable electric power, including: a) implementation of smart grid management systems based on digital technologies, b) development of centralized energy systems, c) development of distributed generation, renewable energy, including remote and isolated areas.

As part of this federal program, an industry-specific project called "Digital Energy" was formed. Its agenda was approved at the end of 2018 with the purpose of supporting the digital development of power engineering, the oil and gas industry and coal mining [20]. The project is aimed at systematizing the experience of the implementation of digital technologies, at ensuring clear goals for the digitalization of the energy sector and setting basic requirements and criteria for solutions being implemented, and at digital transformation monitoring. Cooperation between the ministry, the expert community and businesses is an effective tool for the implementation of the project. The part of the project that is universal throughout the industry envisages the creation of conditions for designing and developing digital services and solutions in specific branches of the fuel and energy sector.

There is, however, a need for a specific approach to the digitalization of the electric power industry. For this reason, the Energy Ministry of Russia initiated in 2019 a separate ministerial project called "Unified Technical Policy - Power Supply Reliability". It is aimed at creating conditions for the implementation of risk-oriented industrial energy asset management by refining the legal and technical regulatory framework of the electric power industry [21].

On 9 June 2020, the new "Energy Strategy of Russia through to 2035" was approved [22]. It is this document that sets the goal of "the digital transformation and "smartization" of the energy and fuel industries" [22] and makes references to the NTI EnergyNet road map and sector-specific projects of the Energy Ministry. The projected outcomes of the strategy implementation are [22]:

- creation of a system for control, coordination and monitoring of the fuel and energy sector transformation;

- integration of digital technology into state governance and oversight activities in the fuel and energy industries;

- implementation of pilot projects to implement digital technology and platform solutions tailored to the sector;

- a transition to risk-oriented industrial asset management on the basis of digital technology;

- creation of smart electricity metering systems etc. 


\section{Current results of "EnergyNet" road map implementation}

All projects that are being implemented as part of the EnergyNet program are divided into four groups [23]:

- Flagship projects: major and backbone projects (supported by [13]);

- Comprehensive projects: pilot projects aimed at testing technical, economic, organizational and regulatory aspects of new business practices in the field of power engineering;

- Technology projects that are aimed at overcoming the technological barriers of the "EnergyNet" road map (under implementation in cooperation with the Foundation for Assistance to Small Innovative Enterprises);

- Regulatory projects that are aimed at refining legislation and eliminating administrative barriers [24].

Table 1. "EnergyNet" flagship projects

\begin{tabular}{|c|c|c|c|}
\hline Project & Year & Status & Contents \\
\hline $\begin{array}{l}\text { Digital PDA - } \\
\text { YantarEnergo }\end{array}$ & 2018 & Completed & $\begin{array}{l}\text { - Commercial technology prototypes for digitalization of a } \\
\text { grid company } \\
\text { - Technology trials in pilot zones } \\
\text { - Verification of potential technical and economic effects } \\
\text { and target performance indicators of a model grid company } \\
\text { - Initiatives to adjust regulatory and technical } \\
\text { documentation in order to replicate project results }\end{array}$ \\
\hline $\begin{array}{l}\text { Internet of } \\
\text { Energy } \\
\text { architecture }\end{array}$ & 2018 & Completed & $\begin{array}{l}\text { - Development of decentralized energy system } \\
\text { - Application of smart distributed control to be carried out } \\
\text { through energy transactions } \\
\text { - Adherence to the principles of transaction, intelligence, } \\
\text { sustainability and flexibility }\end{array}$ \\
\hline Energozapas & 2018 & In progress & $\begin{array}{l}\text { - Creation of lifted weight storage plant (with capacity } \\
\text { above } 300 \mathrm{MWh} \text { ) }\end{array}$ \\
\hline Topaz & 2018 & In progress & $\begin{array}{l}\text { - Creation of portable power source that is capable of } \\
\text { continuously generating electricity from organic fuel at } \\
\text { temperatures ranging from minus } 40 \text { to plus } 50 \text { degrees } \\
\text { Celsius (with capacity of } 3,000 \text { watt-hour per kg) }\end{array}$ \\
\hline$« \forall$ Platform & 2019 & In progress & $\begin{array}{l}\text { - Smart distributed energy } \\
\text { - Provision to consumers of high-quality low-cost } \\
\text { mechanisms of accessing the full range of capabilities and } \\
\text { functions of energy sector actors }\end{array}$ \\
\hline CableWalker & 2019 & In progress & $\begin{array}{l}\text { - Pilotless transport platform, inspection and maintenance } \\
\text { modules, software and automated expert system of defect } \\
\text { detection } \\
\text { - Detailed monitoring and technical maintenance of } \\
\text { transmission wires, condition-based repairs } \\
\text { - Precision investment in specific trouble areas and } \\
\text { extension of service life } \\
\text { - Reducing the human factor; reducing failure occurrence }\end{array}$ \\
\hline
\end{tabular}

The structure of the EnergyNet projects and their contents are briefly presented in Tables 1 [25-30] and 2 [31]. 
Table 2. Some "EnergyNet" technology projects being implemented since 2020

\begin{tabular}{|l|l|}
\hline Initiating company & Contents \\
\hline Iserv & $\begin{array}{l}\text { Digital platform for automation of processes of transportation and selling of } \\
\text { energy and utilities }\end{array}$ \\
\hline ANSystems & $\begin{array}{l}\text { Decision Support System in the energy sector on the basis open digital } \\
\text { ontologies with the capability of crowdsourced structure building and editing }\end{array}$ \\
\hline Optispark & Solar-blind filters for inspection of overhead power lines \\
\hline Technotronics & Battery monitoring and predictive analytics system \\
\hline ELIOT & $\begin{array}{l}\text { Platform for electricity bill calculation and payment on the basis of smart } \\
\text { contracts }\end{array}$ \\
\hline DonEnergoMash & $\begin{array}{l}\text { Simulation modeling, creation of management algorithms and software for } \\
\text { automated control over MicroGrid smart energy system }\end{array}$ \\
\hline
\end{tabular}

In 2020, a total of eight technology projects received support; in 2019 - five; in 2018 15 ; in $2017-15$; in $2016-21$ [31].

Comprehensive projects within the "EnergyNet" framework are being implemented in six areas [32]:

- active energy complexes;

- demand-side management aggregators;

- power supply to isolated and remote areas;

- use of energy storage systems;

- digital distribution electrical networks;

- user services.

Regulatory projects "EnergyNet" are distributed among five segments [33]:

- Development of active energy complexes;

- Development of the electrical energy storage systems market;

- Development of the demand-side management (DSM) market on the basis of DSM aggregators;

- Digital grids - improving the quality of electrical power supply services;

- Concessions - ensuring return on investment in smart energy.

The above projects have already won recognition in the domestic and international markets. For example, the "CableWalker" project received exceptional attention at the international trade show Middle East Electricity [34]. Trial runs of its pilot projects are being conducted by Russian company Rosseti Urala and by Saudi Electricity Company.

\section{Current results of "Digital Energy" project}

The departmental project Digital Energy implies a more methodical approach as compared to other programs. This is the deciding factor in its current results [20]:

- Creation of the council for digital transformation of the branches of the energy industry.

The purpose of the council is to work out a unified stance and key decisions regarding the digital transformation of the entire fuel and energy sector. Its creation was the first step towards the formation of an all-encompassing system for coordination and monitoring of digital transformation.

- Creation of centers of competence in the electric power industry, the oil and gas industry and coal mining. 
They mainly serve to determine priority areas of action and technologies for the industries, to identify regulatory and technological barriers to implementation, as well as to create digital development road maps for the industries. The centers of competences were established by leading companies of the fuel and energy sector in cooperation with the Energy Ministry of Russia.

- Drafting of the core document for the digital development of the Russian energy sector - the Concept of the Digital Transformation of the Fuel and Energy Sector for the mid-term (through to 2024) and long-term (through to 2035) period. The concept contains scenarios, forecasts and priority action areas in terms of the digitalization of the sector.

Applied projects of energy digitalization are being implemented as part of another departmental project. They are described in the following section.

\section{Current results of the "Unified Technical Policy - Power Supply Reliability" project}

This departmental project envisages the implementation of 25 pilot projects at various energy companies before the end of 2024. The shared goal of the projects is to refine the legal and technical regulatory framework for the adoption of risk-oriented industrial energy asset management.

One of the projects that aimed to design "A digital model of a power grid and electricity delivery points" [35] in compliance with national standards was implemented by MRSK South (a subsidiary of Rosseti). As an outcome, trials were conducted to test the collection of input data for calculating the reliability of services being provided by utilities on the basis of the Industrial Internet. In the future, this solution could enable accurate and fast assessment of reliability metrics from the consumers' perspective and make it possible to improve operations and technology control and situational management processes in power networks.

A pilot project implemented by Kubanenergo (also a Rosseti subsidiary) [36] created a tool that uses an approved method [37] for automated calculation of the probability and impacts of a failure and technical risks. Further development of intelligent systems built upon algorithms that generate forecasts on the basis of measurements done by an automated monitoring and diagnosis system would make it possible to get a more precise list of priority equipment for technical operations.

A joint project by the System Operator of the United Energy System and RusHydro resulted in the launch of a digital remotely controlled load shedding system for ten hydroelectric power plants. The system is operated by control centers. The project was a step forward in the deployment of digital remote equipment control and work schedule management at energy facilities [38].

In addition, Rosseti's Mobile Gas-Turbine Power Stations group presented a pilot project aiming to create a prototype system for predictive analysis of energy generating equipment using intelligent data processing approaches [39]. As part of the project, models and methods were developed for predictive analysis of the main elements and units, detection of performance deviations, prediction of actual equipment status.

\section{Conclusions}

The modern world is witnessing the beginning of the fourth energy transition that will go through stages of the digitalization of the energy sector, including widespread use of unconventional renewable energy sources, a bigger role of distributed generation, the development and improvement of energy accumulation and storage systems. The objective 
of the new energy transition is to enhance energy security, energy efficiency; to make energy more accessible and greener; to make renewable energy competitive as innovations in the market reach critical mass.

The Russian economy, too, is actively involved in step-by-step digitalization of industries, including the fuel and energy sector. To achieve that, not only relevant regulatory documents are being drafted, but also targeted incentives are being proposed to facilitate the creation and adoption of digital technologies. For example, the EnergyNet action plan and the departmental project "Unified Technical Policy - Power Supply Reliability" were developed. They serve as umbrella projects for the design of new models of digitalization of grid companies, the development of decentralized energy systems, the creation of efficient energy storage systems, portable power sources etc. Russian technical solutions are sought after in the international energy market. Being a product of synergy of the state, businesses, the innovation community and science, such projects ensure the maximum system effect of digitalization.

According to experts, there is a number of global digital trends that will be actively implemented in the near future: digitalization of infrastructure; decentralization of power generation; intelligent control and engineering; the increasing appeal of the sector to private investors; dismantlement of regulatory barriers for business; introduction of a new generation of Impact Investing economic technologies; creation of new opportunities for end consumers of energy, service organizations, etc.

\section{Acknowledgement}

The work was supported by Grant of the President of the Russian Federation (MK4549.2021.2).

\section{References}

1. B.E. Murmansky, K.E. Aronson, Y.M. Brodov, Journal of Physics: Conference Series, 891, 012279 (2017)

2. L.D. Gitelman, B.E. Ratnikov, Economics and business in the electric power industry [Ekonomika i biznes $v$ elektroenergetike] (2013)

3. V. Panchenko, Y. Harust, Y. Us, O. Korobets, V. Pavlyk, Marketing and Management of Innovations, 1, 256-264 (2020)

4. Y. Wu, Y. Wu, J.M. Guerrero, J.C. Vasquez, International Journal of Electrical Power and Energy Systems, 126, 106593 (2021)

5. E. Lisin I. Lebedev E. Sukhareva I. Komarov, International Economics Letters, 3(3), 105-114 (2014)

6. G. Chebotareva, W. Strielkowski, D. Streimikiene, Journal of Cleaner Production, 269, $122110(2020)$

7. L. El Iysaouy, N.E. El Idrissi, M. Tvaronavičienė, M. Lahbabi, A. Oumnad, Insights into Regional Development, 1(3), 259-271 (2019)

8. R. Carmichael, R. Gross, R. Hanna, A. Rhodes, T. Green, Renewable and Sustainable Energy Reviews, 139, 110701 (2021)

9. O. Konova I. Komarov E. Lisin, Czech Journal of Social Sciences, Business and Economics, 1(1), 101-109 (2012)

10. Message of the President of the Russian Federation to the Federal Assembly [Poslanie Prezidenta RF Federal'nomu

http://www.consultant.ru/document/cons_doc_LAW_171774(2014) 
11. National Technology Initiative: Russia's Leadership in Global Technology Markets by 2035 [Nacional'naya tekhnologicheskaya iniciativa: liderstvo Rossii na global'nyh tekhnologicheskih rynkah $\mathrm{k} 2035$ godu], https://www.rvc.ru/pressservice/news/company/41396 (2015)

12. National Technology Initiative. Dossier [Nacional'naya tekhnologicheskaya iniciativa. Dos'e], https://tass.ru/info/4421323 (2017)

13. Government Resolution "On the Implementation of the National Technology Initiative" [Postanovlenie pravitel'stva "O realizacii Nacional'noj tekhnologicheskoj iniciativy"], https://base.garant.ru/71380666 (2016)

14. Register of NTI projects [Reestr proektov NTI], https://nti2035.ru/upload/353016.2.project_register_NTI_317.pdf(2020)

15. Roadmap "EnergyNet" [Dorozhnaya "EnergyNet"], https://nti2035.ru/documents/docs/DK_energynet.pdf(2016)

16. Regulatory roadmap "EnergyNet" [Normativnaya dorozhnaya karta "EnergyNet"], https://nti2035.ru/documents/docs/NDK_energynet_2020.pdf (2020)

17. Decree of the President of the Russian Federation No. 204 "On National Goals and Strategic Objectives of the Development of the Russian Federation for the period up to 2024" [Ukaz Prezidenta Rossijskoj Federacii 204 "O nacional'nyh celyah i strategicheskih zadachah razvitiya Rossijskoj Federacii na period do 2024 goda"], https://www.primorsky.ru/authorities/executive-agencies/departments/departamentproektov/Ukaz\%20204/Указ\%20Президента\%20РФ\%20от\%2007.05.2018\%20z.\% 20№\%20204.pdf (2018)

18. National Program Digital Economy [Nacional'naya programma Cifrovaya ekonomika], https://digital.ac.gov.ru (2018)

19. Passport of the national program "Digital Economy of the Russian Federation" [Pasport nacional'noj programmy "Cifrovaya ekonomika Rossijskoj Federacii"], http://government.ru/info/35568 (2019)

20. Departmental project "Digital Energy" [Vedomstvennyj proekt "Cifrovaya energetika"],

https://in.minenergo.gov.ru/energynet/docs/Ведомственный\%20проект\%20Цифров ая\%20энергетика\%20-\%20прил\%201.pdf(2018)

21. Departmental project of the Ministry of Energy "Unified Technical Policy - Power Supply Reliability" [Vedomstvennyj proekt Ministerstva energetiki "Edinaya tekhnicheskaya politika - nadezhnost' elektrosnabzheniya"], https://www.digitalenergy.ru/trends/analytics/projects/unified-technical-policy (2019)

22. Russia's Energy Strategy for the period up to 2035 [Energeticheskaya strategiya Rossii na period do 2035 goda], http://static.government.ru/media/files/w4sigFOiDjGVDYT4IgsApssm6mZRb7wx.pdf (2020)

23. Project "EnergyNet" [Proekt "EnergyNet"], https://energynet.ru (2016)

24. Order of the Government of the Russian Federation 1526-r "On Approval of the Action Plan ("Road Map") to improve Legislation and Eliminate Administrative Barriers in order to ensure the implementation of the National Technology Initiative in the direction of "Energinet" [Rasporyazhenie Pravitel'stva RF 1526-r "Ob utverzhdenii plana meropriyatij (“dorozhnoj karty") po sovershenstvovaniyu zakonodatel'stva i ustraneniyu administrativnyh bar'erov v celyah obespecheniya realizacii Nacional'noj tekhnologicheskoj iniciativy po napravleniyu "Enerdzhinet"], http://www.consultant.ru/document/cons_doc_LAW_354841 (2020)

25. Flagship projects of NTI "Energinet" [Flagmanskie proekty NTI "Enerdzhinet"], https://energynet.ru/projects\#!/tab/171646271-1 (2021) 
26. Project "Architecture of the Internet of energy" [Proekt "Arhitektura Interneta energii"], https://idea-go.tech (2021)

27. Project "Energozapas" [Proekt "Energozapas], http://energozapas.ru (2021)

28. Project "Topaz" [Proekt "Topaz"], https://topaz.center/ (2021)

29. Project "A-Platform" [Proekt “A-Platforma"] (2021), https://a-platform.ru/

30. Project "CableWalker" [Proekt "Kanatohod"], https://drive.google.com/file/d/1P8Eo3QruTDTDJ8W0IP6Ht22QPIULpdVu/view (2021)

31. Technological projects of NTI "Energinet" [Tekhnologicheskie proekty NTI "Enerdzhinet"], https://energynet.ru/Projects\#!/tab/171646271-3 (2021)

32. Comprehensive projects of NTI "Energinet" [Kompleksnye proekty NTI "Enerdzhinet"] (2021), https://energynet.ru/Projects\#!/tab/171646271-2 (2021)

33. Regulatory projects of NTI "Energinet" [Regulyatornye proekty NTI "Enerdzhinet"], https://energynet.ru/Projects\#!/tab/171646271-4 (2021)

34. The project "CableWalker" conquers the world [Proekt "Kanatohod" pokoryaet mir], https://urfu.ru/ru/news/23003/ (2018)

35. The Ministry of Energy approved a pilot project to determine the reliability of energy supply indicators based on the digital network topology [V Minenergo byl odobren pilotnyj proekt po opredeleniyu pokazatelej nadezhnosti energosnabzheniya po cifrovoj topologii seti], https://digitalsubstation.com/blog/2020/03/08/v-minenergo-bylodobren-pilot-po-opredeleniyu-pokazatelej-nadezhnosti-energosnabzheniya-potsifrovoj-topologii-seti (2021)

36. The Ministry of Energy considered a pilot project in the field of predictive analysis of equipment condition [V Minenergo rassmotreli pilotnyj proekt $\mathrm{v}$ oblasti prediktivnogo analiza sostoyaniya oborudovaniya], https://digitalsubstation.com/blog/2020/04/09/vminenergo-rassmotreli-pilotnyj-proekt-prediktivnogo-analiza-sostoyaniyaoborudovaniya (2021)

37. Order of the Ministry of Energy of the Russian Federation 123 "On Approval of Methodological Guidelines for Calculating the Probability of Failure of a Functional Unit and a Unit of Basic Technological Equipment and Assessing the Consequences of such a Failure" [Prikaz Ministerstva energetiki RF 123 "Ob utverzhdenii metodicheskih ukazanij po raschetu veroyatnosti otkaza funkcional'nogo uzla i edinicy osnovnogo tekhnologicheskogo oborudovaniya i ocenki posledstvij takogo otkaza"], https://www.garant.ru/products/ipo/prime/doc/72113770/ (2019)

38. The System operator suggests using remote control technologies in thermal generation [Sistemnyj operator predlagaet primenyat' tekhnologii distancionnogo upravleniya $\mathrm{v}$ teplovoj generacii], https://www.eprussia.ru/news/base/2020/2151473.html (2020)

39. Digital predictive analysis of the operation of power generation equipment [Cifrovaya sistema prediktivnogo analiza raboty generiruyushchego oborudovaniya], https://energypolicy.ru/czifrovaya-sistema-prediktivnogo-anal/energetika/2020/13/10 (2020) 